\title{
Perilaku Merokok Siswa-Siswi Sekolah Menengah Pertama (SMP) di Wilayah Kerja Puskesmas Sei Agul Medan
}

\author{
Sri Novita Lubis ${ }^{1}$, Dhani Syahputra Bukit ${ }^{2}$ \\ ${ }^{1,2}$ Fakultas Kesehatan Masyarakat, Universitas Sumatera Utara, Indonesia \\ Email: srinovita@usu.ac.id
}

\begin{abstract}
Smoking Behavior Among Students of Junior High School In The Working Area of Puskesmas SeiAgul Medan. Cigarettes are one of the tobacco products that contain addictive substances and other ingredients that are harmful to health both directly and indirectly. According to RisetKesehatanDasar (Riskesdas), there is a trend in the age of smoking that is increasingly young from year to year. This study aims to describe smoking behavior among students of junior high school in the working area of PuskesmasSeiAgul Medan. This research was a descriptive study with a cross-sectional study. The population of this study was all the male and female students in grade 8 of junior high school. There were a total of 384 samples. Data were collected with a questionnaire. The results showed that the prevalence of ever smoking was 32,6\%. The respondents who have smoking habits was $85,6 \%$. The highest number of consumption cigarettes was $<1$ cigarette per day $(72,8 \%)$ and the lowest was $11-20$ cigarettes per day $(1,0 \%), 76,3 \%$ have a family history of smoking, and $58,1 \%$ had a smoking friend. A total of $98,2 \%$ of respondent have been exposed to cigarette advertisements and 63,3\% often see cigarette advertisements. The average pocket money was Rp9.567,57. The average cost that spent on cigarettes was $\mathrm{Rp}$ $3.473,68$.
\end{abstract}

Keywords: Junior high school, Smoking behavior, Students

\begin{abstract}
Abstrak: Perilaku Merokok Siswa-Siswi Sekolah Menengah Pertama (SMP) di Wilayah Kerja Puskesmas Sei Agul Medan. Rokok adalah salah satu produk tembakau yang mengandung zat adiktif dan bahan lainnya yang berbahaya bagi kesehatan baik secara langsung maupun tidak langsung. Berdasarkan data Riskesdas ada trend umur merokok yang semakin belia dari tahun ke tahun. Penelitian bertujuan untuk mengetahui gambaran perilaku merokok pada siswa-siswi Sekolah Menengah Pertama (SMP) di wilayah kerja puskesmas Sei Agul Medan. Penelitian ini adalah penelitian deskriptif dengan desain studi potong-lintang (cross-sectional). Populasi dalam penelitian ini adalah seluruh siswa-siswi kelas 8 sekolah menengah pertama di wilayah kerja Puskesmas SeiAgul Medan dengan jumlah sampel 384 orang. Data dikumpulkan dengan teknik wawancara menggunakan kuesioner. Hasil penelitian menunjukkan bahwa prevalensi pernah mencoba merokok sebesar 32,6\%. Responden yang memiliki kebiasaan merokok sebesar 85,6\%. Jumlah batang rokok yang tertinggi yang dihisap responden adalah $<1$ batang/hari sebesar 72,8\% dan terendah 11-20 batang/hari sebesar 1,0\%, sebanyak 76,3\% responden memiliki riwayat keluarga merokok, dan sebanyak $58,1 \%$ responden memiliki teman sebaya yang merokok. Responden yang pernah terpapar dengan iklan rokok sebesar 98,2\% dan 63,3\% sering melihat iklan rokok. Rata-rata uang saku yang dimiliki responden sebesar Rp 9.567,57. Rata-rata jumlah uang saku yang dihabiskan untuk membeli rokok sebesar Rp 3.473,68.
\end{abstract}

Kata kunci: Sekolah menengah pertama, Perilaku merokok, Siswa-siswi

\section{PENDAHULUAN}

Produk tembakau merupakan suatu produk yang secara keseluruhan atau sebagian terbuat dari daun tembakau sebagai bahan bakunya yang diolah untuk digunakan dengan cara dibakar, dihisap, dan dihirup atau dikunyah. Produk tembakau yang dimaksud mengandung zat adiktif dan bahan lainnya yang berbahaya bagi kesehatan baik secara langsung maupun tidak langsung (PP RI No. 109, 2012).

Berdasarkan data WHO tahun 2009 setiap tahun terdapat 5,4 juta orang yang meninggal akibat rokok dan itu akan meningkat menjadi 8 juta pada tahun 2030. Hampir seluruh perilaku merokok dimulai saat usia muda dan terus berlangsung sampai usia dewasa. Lebih dari 3.200 anak-anak usia 18 tahun atau lebih muda menghisap rokok setiap hari. 9 dari 10 perokok 
mulai merokok sebelum usia 18 dan hampir semua mulai merokok pada usia 26 tahun. Setiap orang dewasa yang meninggal lebih awal karena merokok digantikan oleh dua perokok muda baru. Jika merokok terus pada tingkat saat ini, 5,6 jutaatau 1 dari setiap 13 anak hari ini akhirnya mati sebelum waktunya karena penyakit yang berhubungan dengan merokok (CDC, 2014).

Indonesia mengalami peningkatan terbesar perilaku merokok yang cenderung dimulai pada usia yang semakin muda. Pada usia 10-14 tahun, terdapat $0,5 \%$ remaja yang merokok setiap hari dan 0,9\% merokok kadang-kadang (Kemenkes RI, 2013).

Masa remaja merupakan masa yang rawan atau masa panca roba, pada periode ini mereka senang mencoba sesuatu hal yang baru apalagi ada mitos bahwa jika seorang sudah merokok, dia dianggap mampu meningkatkan daya konsentrasi, memperlancar kemampuan pemecahan masalah, meredakan ketegangan, meningkatkan kepercayaan diri dan penghalau kesepian (Aula, 2010).

Angka yang didapat dari hasil survei yang dilakukan General Youth Tobacco Survey (GYTS) Indonesia menunjukkan bahwa 30\% anak Sekolah Menengah Pertama (SMP) di Jakarta, Bekasi, dan Medan ternyata sudah merokok. Di wilayah Jakarta diketahui bahwa terdapat 34\% murid sekolah usia SMP pernah merokok dan sebanyak $16,6 \%$ masih merokok. Di Bekasi, 33\% murid sekolah usia SMP pernah merokok dan sebanyak $17,1 \%$ saat ini masih merokok. Sedangkan di Kota Medan diperoleh hasil survei sebesar 34,9\% murid sekolah usia SMP pernah merokok dan sebanyak $20,9 \%$ saat ini masih merokok (Widowaty, 2008).

Kota Medan sebagai ibu kota Provinsi Sumatera Utara merupakan kota nomor 3 terbesar di Indonesia. Sebagai ibu kota Provinsi, maka sudah tentulah proporsi perokok remaja di Kota Medan juga cukup besar. Seluruh sekolah di Kota Medan memiliki kebijakan tidak memperbolehkan siswa-siswinya merokok di lingkungan sekolah, bahkan melakukan razia rutin rokok pada siswasiswinya sebagai upaya untuk menghindarkan siswa dan siswinya merokok di lingkungan sekolah. Mengingat ketatnya kebijakan yang dibuat, seharusnya konsumsi rokok pada siswa dan siswi berkurang, tetapi tidak begitu pada kenyataanya. Dalam kondisi di lapangan masih sering dijumpai siswa-siswi yang merokok baik dilingkungan sekolah maupun diluar sekolah pada jam sekolah. Jumlah perokok pada remaja di wilayah kerja puskesmas Sei Agul menurut observasi awal peneliti sangat tinggi, kemudian akses remaja dalam mendapatkan rokok dan informasi rokok sangat terjangkau dengan banyaknya iklan rokok yang tersedia di sekitar wilayah sekolah serta warung kecil yang berdekatan dengan sekolah juga menyediakan rokok buat anak sekolah.

Berdasarkan latar belakang di atas peneliti tertarik untuk melakukan penelitian tentang perilaku merokok pada siswa-siswi SMP di wilayah kerja Puskesmas Sei Agul Medan.

\section{METODE}

Jenis Penelitian yang digunakan adalah penelitian deskriptif dengan menggunakan pendekatan cross-sectional. Penelitian dilakukan di Sekolah Menengah Pertama (SMP) yang ada di wilayah kerja Puskesmas Sei Agul Kecamatan Medan Barat yaitu SMP Negeri 16 Medan, SMP Swasta Karya Bakti, dan SMP Swasta Nasrani 3. Populasi dalam penelitian ini adalah seluruh siswa kelas 8 dengan pertimbangan kemampuan siswa untuk terlibat dalam penelitian tersebut. Sampel penelitian berjumlah 384 orang yang termasuk dalam kriteria inklusi adalah seluruh siswa kelas 8 yang terdaftar dan hadir pada saat penelitian dilaksanakan. Sedangkan kriteria eksklusinya adalah siswa kelas 8 yang tidak bersedia ikut serta dalam penelitian. Pengambilan sampel dengan simple random sampling. Data akan dianalisis secara deskriptif untuk mendapatkan gambaran perilaku merokok pada siswa-siswi SMP yang ada di wilayah kerja Puskesmas Sei Agul Medan.

\section{HASIL}

Tabel 1. Prevalensi Perilaku Merokok di Sekolah Menengah Pertama (SMP)

\begin{tabular}{lcc}
\hline \multicolumn{1}{c}{ Perilaku merokok } & Frekuensi & $\%$ \\
\hline Pernah mencoba merokok & & \\
- Pernah & 125 & 32,6 \\
- Tidak pernah & 259 & 67,4 \\
\hline Kebiasaan merokok & & \\
- Ya & 107 & 85,6 \\
- Tidak & 18 & 14,4 \\
\hline
\end{tabular}

Dari hasil penelitian didapatkan bahwa prevalensi siswa-siswi yang pernahmencoba merokok adalah 32,6\%. Responden yang memiliki kebiasaan merokok sebanyak 107 orang $(85,6 \%)$ dan tidak memiliki kebiasaan merokok sebanyak 18 orang $(14,4 \%)$. 
Tabel 2. Perilaku Merokok di Sekolah Menengah Pertama (SMP)

\begin{tabular}{lrr}
\hline \multicolumn{1}{c}{ Variabel } & Frekuensi & \% \\
\hline Jumlah batang rokok yang & & \\
dihisap & 78 & 72,8 \\
- 1 batang/hari & 26 & 24,2 \\
1-5 batang/hari & 1 & 1,0 \\
- 11-20 batang/hari & 2 & 2,0 \\
> 20 batang/hari & & \\
\hline Riwayat keluarga & 293 & 76,3 \\
merokok & 91 & 23,7 \\
Ada & & \\
Tidak ada & & \\
Teman sebaya perokok & 223 & 58,1 \\
Ya & 161 & 41,9 \\
- Tidak & & \\
\hline Keterpaparan iklan rokok & 377 & 98,2 \\
Pernah & 7 & 1,8 \\
Tidakpernah & & \\
\hline Frekuensi keterpaparan & & \\
iklan rokok & 243 & 63,3 \\
Setiap hari & 97 & 25,3 \\
Sering (3-4 kali/minggu) & 36 & 9,4 \\
Jarang (2 minggu sekali) & 8 & 2,1 \\
Tidak pernah & & \\
\hline
\end{tabular}

Berdasarkan jumlah batang rokok yang dihisap per hari terbanyak menghisap rokok $<1$ batang/hari sebesar 78 orang $(72,8 \%)$ dan paling sedikit menghisap rokok 11-20 batang/hari sebesar 1 orang (1\%). Berdasarkan riwayat keluarga perokok terbanyak responden memiliki riwayat keluarga perokok sebesar 293 orang $(76,3 \%)$ dan tidak memiliki riwayat keluarga merokok sebesar 91 orang $(23,7 \%)$. Distribusi proporsi responden terbanyak memiliki teman sebaya yang merokok sebesar 223 orang $(58,1 \%)$ dan tidak memiliki teman sebaya yang merokok sebesar 161 orang $(41,9 \%)$, distribusi proporsi responden terbanyak yang pernah terpapar dengan iklan rokok sebesar 377 orang $(98,2 \%)$ dan tidak pernah terpapar dengan iklan rokok sebesar 7 orang $(1,8 \%)$. Berdasarkan keterpaparan iklan rokok terbanyak responden sering melihat iklan rokok sebesar 243 orang $(63,3 \%)$ dan paling sedikit tidak pernah terpapar dengan iklan rokok sebesar 8 orang $(2,1 \%)$.

Tabel 3. Distribusi Responden Berdasarkan Uang Saku

\begin{tabular}{lcc}
\hline Kepemilikan uang saku & Frekuensi & \% \\
\hline Ya & 333 & 86,7 \\
Tidak & 51 & 13,3 \\
\hline
\end{tabular}

Tabel 4. Distribusi Responden Berdasarkan Rata-Rata Uang Saku

\begin{tabular}{ll}
\hline & Rata-Rata Uang Saku \\
\hline Mean & $: \operatorname{Rp} 9.567,57,-$ \\
Minimum & $: \operatorname{Rp~1.000,-}$ \\
Maximum & $:$ Rp 50.000,- \\
\hline
\end{tabular}

Tabel 5. Distribusi Responden Berdasarkan Rata-Rata Uang Saku yang Dihabiskan Untuk Membeli Rokok

Rata-Rata Uang Saku yang Dihabiskan untuk Membeli Rokok

Mean : Rp 3.473,68,-

Minimum : Rp 1.000,-

Maximum : Rp 15.000,-

Berdasarkan kepemilikan uang saku sebanyak 333 orang $(86,7 \%)$ responden memiliki uang saku (Tabel 3). Rata-rata uang saku yang dimiliki responden sebesar Rp 9.567,57. Jumlah uang saku yang paling minimum sebesarRp 1.000,00 dan maksimum sebesarRp 50.000,00 (Tabel 4). Rata-rata jumlah uang saku yang dihabiskan untuk membeli rokok sebesar Rp $3.473,68$. Jumlah uang saku minimum yang dihabiskan untuk membeli rokok sebesarRp 1.000,00 dan maksimum Rp 15.000,00 (Tabel 5).

\section{PEMBAHASAN}

Hasil penelitian yang dilakukan pada siswa-siswi SMP di wilayah kerja Puskesmas Sei Agul Medan menunjukkan bahwa prevalensi siswa-siswi yang pernah merokok adalah 32.6\%. Hal ini sejalan dengan data Kemenkes RI tahun 2016 yang menunjukkan bahwa usia mulai merokok semakin muda (dini). Perokok pemula usia 10-14 tahun meningkat lebih dari 100\% dalam kurun waktu kurang dari 20 tahun, yaitu dari $8,9 \%$ di tahun 1995 menjadi $18 \%$ di tahun 2013 (Kemenkes RI, 2016).

Global Youth Tobacco Survey (GYTS) menunjukkan Indonesia sebagai negara dengan angka perokok remaja tertinggi di dunia. Usia pertama kali mencoba merokok berdasarkan kelompok umur dan jenis kelamin berdasarkan GYTS 2014, dimana sebagian besar laki-laki pertama kali merokok pada umur 12-13 tahun dan sebagian besar perempuan pertama kali mencoba merokok pada umur $\leq 7$ tahun dan 14-15 tahun (Infodatin, 2014).

Rendahnya umur untuk memulai merokok ini didukung oleh studi yang menunjukkan bahwa sepertiga pelajar di Indonesia mulai merokok pada usia kurang dari 10 tahun. Kondisi ini menjadi suatu ancaman karena rendahnya umur untuk memulai merokok akan meningkatkan risiko menjadi perokok dalam jangka waktu yang lebih lama. Rendahnya umur mulai merokok memiliki efek yang lebih buruk bagi kesehatan karena ada hubungan yang bermakna antara perokok aktif saat anak-anak dan remaja dengan kejadian kerusakan fungsi paru-paru, asma, dan aterosklerosis (U.S. 
Department of Health and Human Services, 2012).

Rerata jumlah batang rokok yang dihisap setiap hari yang paling tinggi adalah $<1$ batang/hari $(72,8 \%)$. Hal ini dapat diasumsikan bahwa perilaku merokok responden masih dalam tahap coba-coba. Survei GYTS tahun 2014 menunjukkan bahwa sebagian besar responden umur 13-15 tahun rerata jumlah batang rokok yang dihisap per hari <1 batang sebesar $36 \%$ (Infodatin, 2014). Sehingga perilaku merokok pada siswa-siswi SMP ini dikategorikan sebagai perokok ringan. Perokok ringan apabila merokok kurang dari 10 batang per hari (Bustan, M.N., 2007).

Keluarga berperan strategis membentuk sikap remaja dan sebagai tempat pembelajaran pertama seorang remaja. Orangtua merupakan teladan bagi anak-anak, interaksi yang mendalam antara orangtua dan anak melahirkan karakter yang sama (Rachmat, M., dkk, 2013). Hampir seluruh responden $(76,3 \%)$ memiliki riwayat keluarga merokok dan anggota keluarga yang terbanyak merokok adalah ayah $(93,9 \%)$. Hasil penelitian Muliyana tahun 2013 menunjukkan ada hubungan antara dukungan keluarga dengan praktik merokok. Keluarga khususnya orangtua seharusnya memberikan contoh kepada anakanaknya agar tidak merokok. Orangtua yang merokok memberikan kemungkinan anakanaknya juga akan cenderung meniru perilaku merokok tersebut (Muliyana, D., 2013).

Penelitian kualitatif menunjukkan bahwa remaja perokok kebanyakan melihat orang tua yang pertama kali dilihat merokok, baik dari bapak, ibu maupun keluarga yang lain. Dengan melihat orang tua mereka merokok maka timbul rasa pada diri mereka untuk mencoba apa yang dilakukan orangtua mereka, yang salah satunya perilaku merokok (Widiansyah, M., 2014).

Penelitian Alamsyah tahun 2009 menunjukkan bahwa responden yang orang tuanya merokok mempunyai kebiasaan merokok 1,38 kali dibandingkan yang orang tuanya tidak merokok (Alamsyah, R.M., 2009). Risiko permulaan merokok anak-anak dengan orangtua yang merokok meningkat sesuai dengan durasi mereka terpapar dengan orang tua yang merokok. Anak-anak dari orang tua yang telah berhenti merokok berisiko merokok lebih tinggi dibandingkan dengan anak-anak dengan orang tua yang tidak pernah merokok (Albers $\mathrm{AB}$ et al, 2008).

Hasil Penelitian menunjukkan sekitar $58.1 \%$ responden memiliki teman sebaya perokok. $32.3 \%$. Teman sebaya akan menularkan perilaku merokok dengan cara menawari teman- teman lain tentang kenikmatan merokok, atau solidaritas kelompok. Dari teman sebaya ini kemudian mereka yang belum merokok menginterpretasi bahwa dengan merokok dia akan mendapatkan kenyamanan, dan atau dapat diterima oleh kelompok, dari hasil interpretasi tersebut kemungkinan remaja membentuk dan memperkokoh anticipatory belief, yaitu belief yang mendasari bahwa remaja membutuhkan pengakuan teman sebaya (Levethal, H., 1980). Oleh sebab itu remaja sudah seharusnya lebih selektif dalam memilih teman sebayanya agar tidak mudah tergiur untuk menjadi seorang perokok.

Hasil penelitian menunjukkan bahwa sebanyak 98,2\% responden pernah terpapar dengan iklan rokok, 63,3\% menyatakan setiap hari terpapar dengan iklan rokok, dan 23,2\% responden menyatakan bahwa iklan rokok dapat mendorong seseorang untuk merokok. Hasil penelitian ini sejalan dengan survei yang dilakukan oleh Global Adult Tobacco Survey tahun 2011 yang menyatakan sebanyak 86,4\% responden pernah melihat iklan rokok, sponsor atau promosi (WHO, 2012). Melihat iklan rokok di media massa maupun media elektronik yang menampilkan gambaran bahwa perilaku merokok merupakan lambang kejantanan sehingga menyebabkan remaja mempunyai keinginan untuk meniru apa yang disajikan pada iklan tersebut. Seharusnya dilakukan pembatasan terhadap iklan rokok apakah itu terkait jam tayang maupun lokasi promosinya.

Penelitian yang dilakukan oleh Tarupay tahun 2014 didapatkan hasil bahwa sebagian besar informan menyatakan bahwa mereka terpapar iklan rokok secara tidak langsung (kegiatan yang disponsori rokok, pemberian sampel, reklame rokok, dan iklan komersil rokok di film). Informan mengetahui produk rokok terbaru dari iklan rokok. Tidak ditemukan informan yang memulai merokok karena terpengaruh oleh ajakan iklan, tetapi kemampuan informan mengidentifikasi produk rokok (Tarupay, 2014).

Untuk mengatasi dampak dari iklan dan promosi rokok ini pemerintah telah memberlakukan Peraturan Pemerintah Nomor 109 Tahun 2012 tentang Pengamanan Bahan Yang Mengandung Zat Adiktif Berupa Produk Tembakau Bagi Kesehatan. Peraturan Pemerintah ini kini diperkuat dengan diterbitkannya Peraturan Menteri Kesehatan Nomor 28 tahun 2013 tentang Pencantuman Peringatan Kesehatan dan Informasi Kesehatan pada Kemasan Produk Tembakau. Diharapkan juga partisipasi dari pihak yang terkait baik di tingkat pusat dan 
daerah, bersama seluruh lapisan masyarakat termasuk swasta, agar peraturan perundangan tentang pengendalian tembakau di Indonesia dapat dilaksanakan dengan sungguh-sungguh.

Hasil penelitian menunjukkan sebanyak $86,7 \%$ responden memiliki uang saku. Rata-rata uang saku yang dimiliki responden sebesar Rp 9.567,57. Rata-rata jumlah uang saku yang dihabiskan untuk membeli rokok sebesar $\mathrm{Rp}$ 3.473,68. Penelitian yang dilakukan oleh Waa et al. tahun 2011 di Selandia Baru mendapatkan bahwa pengaturan akan uang saku remaja berpotensi sebagai faktor munculnya perilaku merokok remaja yang disebabkan karena tidak adanya pemantauan dari orangtua terhadap pengeluaran uang saku yang dikaitkan dengan kerentanan terhadap sumber akses merokok (Waa et al, 2011). Potensi terjadinya peningkatan terhadap proporsi remaja perokok yang bersekolah di Shanghai, Cina dapat dicegah dengan cara membatasi jumlah uang saku yang diterima oleh remaja tersebut (Ma J. et al, 2013).

\section{DAFTAR PUSTAKA}

Alamsyah, R.M. (2009). Faktor-Faktor yang Mempengaruhi Kebiasaan Merokok dan Hubungannya dengan Status Penyakit Periodontal Remaja Kota Medan 2007. Medan. (Tesis, Medan: Universitas Sumatera Utara).

Albers, A. B., Biener, L., Siegel, M., Cheng, D. M., \& Rigotti, N. (2008). Household smoking bans and adolescent antismoking attitudes and smoking initiation: findings from a longitudinal study of a Massachusetts youth cohort. American journal of public health,98(10), 18861893.

Aula, Lisa Ellizabet. (2010). Stop Merokok. Yogyakarta: Gara Ilmu.

Bustan M.N. (2007). Epidemiologi Penyakit Tidak Menular. Edisi Kedua. Jakarta: Rineka Cipta.

CDC. (2014). Smoking and Youth. https://www.cdc.gov/tobacco/data_statistic s/sgr/50thanniversary/pdfs/fs_smoking_yo uth_508.pdf

Infodatin. (2014). Perilaku Merokok Masyarakat Indonesia Berdasarkan Riskesdas 2007 dan 2013. Jakarta: Kementerian Kesehatan RI.

Kemenkes RI. (2013). Riset Kesehatan Dasar 2013. Jakarta: Kementerian Kesehatan RI.

\section{SIMPULAN}

Penelitian ini dapat disimpulkan bahwa prevalensi pernah mencoba merokok sebesar $32,6 \%$. Responden yang memiliki kebiasaan merokok sebanyak 107 orang $(85,6 \%)$. Jumlah batang rokok yang tertinggi yang dihisap responden setiap hari adalah <1 batang/hari sebesar 72,8\% dan terendah 11-20 batang/hari sebesar 1,0\%, sebanyak $76,3 \%$ responden memiliki riwayat keluarga merokok, sebanyak $58,1 \%$ responden memiliki teman sebaya yang merokok. Responden yang pernah terpapar dengan iklan rokok sebesar 98,2\%. Sebesar $86,7 \%$ responden memiliki uang saku dengan jumlah uang saku rata-rata sebesar Rp.9.567,57. Jumlah uang saku yang dihabiskan untuk membeli rokok rata-rata sebesar Rp.3.473,68.

Kemenkes RI. (2016). HTTS 2016: Suarakan Kebenaran, Jangan Bunuh Dirimu Dengan Candu Rokok.

http://www.depkes.go.id/article/print/1606 0300002/htts -2016-suarakan-kebenaranjangan-bunuh-dirimu-dengan-candurokok.html.

Levethal, H., \& Cleary, P.D. (1980). The smoking problem: A review of the research and theory in behavioral risk modification. Psychological Bulletin, 88, 370-405.

Ma J. et al. (2013). Cigarette smoking in Chinese adolescents: importance of controlling the amount of pocket money. The Royal Society for Public Health, Published by Elsevier Ltd., 2013 Jul;127(7):687-93. http://www.ncbi.nlm.nih.gov/pubmed/2385 0306.

Muliyana, D., Leida, I. (2013). Faktor Yang Berhubungan Dengan Tindakan Merokok Pada Mahasiswa Universitas Hasanuddin Makassar. Media Kesehatan Masyarakat Indonesia. 2013; Juni, hal 109-119.

Peraturan Pemerintah RI. (2012). PP RI No. 109 Tahun 2012. Tentang Pengamanan Bahan Yang Mengandung Zat Adiktif Berupa Produk Tembakau Bagi Kesehatan. Jakarta.

Rachmat, M, dkk. (2013). Perilaku Merokok Remaja Sekolah Menengah Pertama. 
Jurnal Kesehatan Masyarakat Nasional Vol.7, No.11, Juni 2013.

Tarupay, Aditya. (2014). Perilaku Merokok Mahasiswi Di Kota Makassar. (Karya Tulis Ilmiah, Makassar: Universitas Hasanuddin).

U.S. Department of Health and Human Services. (2012). Preventing Tobacco Use Among Youth and Young Adults: A Report of the Surgeon General. Atlanta, GA: U.S. Department of Health and Human Services, Centers for Disease Control and Prevention, National Center for Chronic Disease Prevention and Health Promotion, Office on Smoking and Health.

Waa et al. (2011). Parental behaviours, but not parental smoking, influence current smoking and smoking susceptibility among 14 and 15 year-old children. Australian and New Zealand Journal of Public Health, Vol. 35, Issue 6. Pg. 530-536, December 2011. Public Health Association of Australia: The Authors ANZJPH. http://onlinelibrary.wiley.com/doi/10.1111/ j.1753-6405.2011.00772.x/full.

WHO. (2012). Global Adult Tobacco Survey: Indonesia Report 2011.

Widiansyah, M. (2014). Faktor-Faktor Penyebab Perilaku Remaja Perokok Di Desa Sidorejo Kabupaten Penajam Paser Utara. eJournal Sosiologi, 2014, 2 (4): 1-12 ISSN 00000000, ejournal.sos.fisip.unmul.

Widowaty, D. P. (2008). Pengaruh Stereotipi Perokok dan Konformitas terhadap Perilaku Merokok pada Siswa SMP. Jakarta: (Skripsi, Jakarta: Ilmu Psikologi Universitas Indonesia). 